\title{
Association of BoLA-DRB3 genotype with somatic cell count in milk of Polish Holstein cattle
}

\author{
Jolanta M. Oprzadek ${ }^{1 \dagger}$, Anna M. Brzozowska ${ }^{1}$, Piotr Urtnowski ${ }^{1}$, Karolina Rutkowska ${ }^{1 *}$, \\ Marek Lukaszewicz ${ }^{1}$
}

\footnotetext{
${ }^{1}$ Institute of Genetics and Animal Breeding of the Polish Academy of Sciences, Jastrzebiec, Poland.

† In memoriam.
}

\begin{abstract}
The objective of this study was to evaluate the suitability of the BoLA-DRB3 gene polymorphism to define the phenotypic value of somatic cell count of 808 Polish Holstein cows. The cows were fathered by 190 sires. The PCR-RFLP alleles were identified with the BstYI, HaeIII, and RsaI restriction enzymes. For statistical analysis, 17 alleles whose frequencies in the herds were equal to or higher than $2 \%$ were selected. Somatic cell count was analyzed based either on the lactation averages or on test-day yields. Significant relationship between the occurrence of the BoLA-DRB3 gene alleles and somatic cell count were stated. In case of estimating the effects for all lactations together, the effect of substitution was observed for 11 alleles. The overall effects of four alleles $(* 12, * 23, * 24$, and $*$ ndb) were statistically significant and their effects were repeated in at least two lactations in the analysis of each lactation separately. The most numerous relationships were found for allele *24, which influences were statistically significant in lactations I to III in the analysis of all lactations together.
\end{abstract}

Key Words: dairy cattle, mammary gland health, marker assisted selection

\section{Introduction}

BoLA-DRB3 gene encodes the $\beta$ chain of MHC class II molecules, which is involved in presenting "non-self" antigen to antigen-presenting cells (APC). The BoLA DRB3 gene is usually expressed by cells of the immune system such as macrophages, dendritic cells, or B lymphocytes, which process the antigen and then present it to the helper $\mathrm{T}$ lymphocytes to unleash the immune response against infectious pathogens. Class II molecules on APC present peptides derived from extracellular pathogens to CD4+ $\mathrm{T}$ cells, which once stimulated activate macrophages and $B$ cells to generate inflammatory and antibody responses, respectively. BoLA-DRB3 is the most polymorphic gene in cattle major histocompatibility complex (MHC); hence, it has been the subject of intensive research for more than twenty years. So far, most of the reports concern the expression and polymorphism of BoLA-DRB3 (van Eijk et al., 1992; Dietz et al., 1997a,b; Sharif et al., 1998; Gillespie

Received: December 4, 2015

Accepted: December 1, 2017

*Corresponding author: k.rutkowska@ighz.pl

Copyright (C) 2018 Sociedade Brasileira de Zootecnia. This is an Open Access article distributed under the terms of the Creative Commons Attribution License (http://creativecommons.org/licenses/by/4.0/), which permits unrestricted use, distribution, and reproduction in any medium, provided the original work is properly cited. et al., 1999; Takeshima et al., 2003; Fernández et al., 2008; Hameed et al., 2008; Duangjinda et al., 2009; Juliarena et al., 2009). Even though the entire BoLA-DRB3 gene was successfully sequenced in the early 90 s of the twentieth century (Groenen et al., 1990), a complete structure of BoLA-DRB3 gene including the length of coding and noncoding sequences was presented after over 10 years (Russell et al., 2004). The polymorphism mainly occurs in the second exon, which encodes the variable part of the MHC class II molecule (Russell et al., 2004), and to a lesser extent, in the third exon (Russell et al., 2000). The primary function of class II molecules is being involved in immune response; therefore, their expression is specific for non-self antigens. Because of the unique structure of regulatory sequences, the expression undergoes specific rules. Regardless of the species, the promoters of MHC class II molecules - in the fragment from 150 to $300 \mathrm{bp}$ upstream of the start codon - are fitted with regulatory module (W-box, X-box, Y-box, CCAAT, TATA), which forms the upstream regulatory region (van den Elsen, 2011). Understanding the role of genetic factors in the phenotypic variability associated with the immune response to pathogens may be a key element in programs aimed at preventing and reducing the occurrence of pathogens. Because molecules encoded by BoLA-DRB3 gene participate in presenting non-self antigens to immune cells, its association with disease resistance seems to be particularly interesting. 
Mastitis is one of the frequent mammary gland diseases impacting lactating animals. Economically, it is considered the most important disease in dairy cattle. Mastitis is a difficult problem to comprehend because it is caused by many factors acting simultaneously. On the most global scale, resistance could be defined as the ability to avoid any infection of the udder or quick recovery from any infection. Most genetic studies have focused on milk somatic cell count (SCC) and clinical mastitis (CM) as phenotypic measure to predict inflammation of the udder. The milk somatic cells include $75 \%$ leucocytes, i.e., neutrophils, macrophages, lymphocytes, erythrocytes, and $25 \%$ epithelial cells. Mastitis is caused by bacterial invasion into the udder. The small numbers of somatic cells that are normally present in milk attempt to resolve this intramammary infection immediately. During bacterial pathogenesis, macrophages serve to facilitate either innate or acquired immune responses. Similar to neutrophils, the non-specific functions of macrophages are to phagocytise invading bacteria and destroy them with proteases and reactive oxygen species. T-lymphocytes and B-lymphocytes are two subsets of lymphocytes that play specific immune functions. The mammary epithelial cells may play a protective role in prevention of infection via ingestion and possible digestion of phagocytosed microbes (reviewed by Sharma et al., 2011). Among genes associated with reduced mastitis incidence, particular attention is paid to the BoLA-DRB 3 gene because of its role in the immune system (reviewed by Sender et al., 2013). The results of our previous study demonstrated that BoLA-DRB3 in the Polish Holstein cattle is highly polymorphic. There is also an indication that differences in frequency of particular alleles may be correlated with differences in production and fitness status of herds (Oprządek et al., 2012).

The objective of this study was to evaluate the suitability of the polymorphism of BoLA-DRB3 gene to define the phenotypic value of somatic cell count (as an indicator of health of the mammary gland) of Polish Holstein cattle.

\section{Material and Methods}

The material consisted of 808 Holstein cows, in three herds. Pedigree data included three generations (animal, parents, and grandparents). Animals originated from 190 sires, of which 134 were represented by at most three daughters, whereas only seven bulls sired 20 or more daughters. Among mothers, only $13.8 \%$ had more than one offspring. In most cases, the relation was limited to two sisters or half-sisters (142 cows), or less often to three sisters from one mother (18 cows).
Production data and functional trait data were collected from 1998 to 2010. Two calving seasons were distinguished: autumn-winter (October-March) and spring-summer (April-September). Twenty-four classes of year and calving seasons were defined. Milk yield, protein, fat, lactose, urea, and dry matter contents as well as SCC were recorded on test days once a month.

Isolation of DNA from blood was performed according to Kanai et al. (1994). The concentration and purity of extracted DNA were assessed by spectrophotometery and electrophoresis in $1 \%$ agarose gel.

The BoLA-DRB3 exon II (including a fragment of intron $\# 1$ ) was amplified by polymerase chain reaction (PCR) using the single step PCR of van Eijk et al. (1992), modified by Oprządek et al. (2012). The PCR was performed in final volume of $32 \mu \mathrm{L}$ containing $40 \mathrm{ng}$ of cDNA, 10 pmol of each primer (HLO30; 5'-ATCCTCTCTCTGCAGCACATTTCC-3' and HLO32; 5'-TCGCCGCTGCACAGTGAAACTCTC-3'), PCR-buffer (20 mM Tris-HCl pH 8.4,50 mM KCl), $1.5 \mathrm{mM}$ $\mathrm{MgCl} 2,0.25 \mathrm{mM}$ of dNTPs, and $1 \mathrm{U}$ of Taq DNA AmpliTag Gold Polymerase, and water for final volume. The PCR was performed as follows: the initial denaturation $\left(94^{\circ} \mathrm{C}\right.$ for 10 min), amplification ( 25 cycles) including denaturation (94 ${ }^{\circ} \mathrm{C}$ for $30 \mathrm{~s}$ ), annealing $\left(65^{\circ} \mathrm{C}\right.$ for $\left.30 \mathrm{~s}\right)$, and elongation $\left(72{ }^{\circ} \mathrm{C}\right.$ for $\left.1 \mathrm{~min}\right)$. The final elongation was carried out at $72{ }^{\circ} \mathrm{C}$ for $5 \mathrm{~min}$. The PCR products were represented by $284 \mathrm{bp}$ fragments as was expected on the basis of the nucleotide sequence of the gene.

The PCR products were digested with three restriction endonucleases: RsaI, HaeIII, and BstYI, as described in van Eijk et al. (1992). They were digested with five units of RsaI and HaeIII at $37^{\circ} \mathrm{C}$ for $3 \mathrm{~h}$ and five units of BstYI at $60{ }^{\circ} \mathrm{C}$ for $3 \mathrm{~h}$. The restriction fragments were resolved on 5\% agarose gel. Fragments of DNA were visualized in UV light and photographed with BioImagine System-Gene Snap (SynGene) using Gene Tools Software, version 4.3.7.

A combination of 1:1 UltraPureTM Agarose (Invitrogen) with NuSieve ${ }^{\circledR}$ GTG $^{\circledR}$ Agarose (Lonza, USA) was used. The use of NuSieve agarose allowed the electrophoretic separation of DNA fragments from $30 \mathrm{bp}$. To prepare the gel, UltraPureTM Agarose and NuSieve Agarose were mixed with $1 \mathrm{x}$ TBE buffer and heated until complete dissolution. After dissolution, it was cooled to about $60{ }^{\circ} \mathrm{C}$ and $2.6 \mu \mathrm{L}$ ethidium bromide was added. Electrophoresis was performed in BioRad in 1x TBE buffer for $1 \mathrm{~h}$.

Exemplary restriction patterns of the BoLA-DRB3.2BstYI gene was shown on the Figure 1.

By solving the regression equations, the estimates of all effects were determined, followed by univariate analysis of variance of examined traits, treating genotype as a grouping 


\begin{tabular}{lccccc}
\hline Lengths of the bands of & \multicolumn{5}{c}{ Restriction patterns of $B o L A-D R B 3.2-B s t Y I$} \\
\cline { 2 - 5 } DNA (bp) & $\mathrm{a}$ & $\mathrm{b}$ & $\mathrm{c}$ & $\mathrm{d}$ & $\mathrm{e}$ \\
\hline 284 & - & - & & & \\
199 & & & & & \\
197 & & & - & & \\
196 & & & & & - \\
112 & & & & - & - \\
87 & - & & - & & - \\
\hline 85 & & & & & \\
\hline
\end{tabular}

Figure 1 - Restriction patterns of the BoLA-DRB3-BstYI gene (example).

factor. To assess the significance of effects of $B O L A-D R B 3$ genotype, the F-statistics were determined in all analyzed classes. If the significance of the relationship between an allele and a trait was confirmed, t tests were conducted for individual samples with respect to the mean value of the trait in the analyzed group. To facilitate the comparison between the effects of individual alleles and genetic effects of other loci, they were expressed as deviations from the mean value of the trait. For statistical analysis, 17 alleles were selected, which frequencies in the herds were equal to or higher than $2 \%$. In the model, the number of copies of the allele was taken into account: 0 - no allele; 1 - allele in a heterozygous genotype; and 2 - allele in a homozygous genotype.

To normalize the distribution of somatic cell count, the SCC was logarithmically transformed ( $\operatorname{lnSCC})$, and all the calculations were run on such values. Somatic cell count changes during the lactation; therefore, the influence of environmental factors on this trait can be eliminated by analyzing the cumulative values of the traits for the whole lactations or, which is more successful, by using a model for daily yields (test-day model - TDM).

The model applied for the phenotypic analysis of test-day $\operatorname{lnSCC}$ was:

$$
\begin{gathered}
\mathrm{y}_{\mathrm{ijkl}}=\alpha+\mathrm{HYS}_{\mathrm{i}}+\mathrm{L}_{\mathrm{j}}+\sum \beta_{1} \text { BoLA }_{\mathrm{ijkl}}+\beta_{1} \mathrm{dd}_{\mathrm{ijkl}}+\beta_{2} \mathrm{dd}_{\mathrm{ij} k \mathrm{l}}^{2}+ \\
\beta_{3} \mathrm{wm}_{\mathrm{ij} \mathrm{jl}}+\mathrm{e}_{\mathrm{ij} \mathrm{jk} l}
\end{gathered}
$$

in which, $\mathrm{y}_{\mathrm{ijkl}}=$ phenotypic value of $\operatorname{lnSCC}$ on the test day; $\alpha=$ intercept; HYS $_{\mathrm{i}}=$ the fixed effect of herd-year-season $(\mathrm{i}=1,44) ; \mathrm{L}_{\mathrm{j}}=$ the fixed effect of subsequent lactation $(\mathrm{j}=1,4) ; \sum \beta_{1} \mathrm{BoLA}_{\mathrm{ijkl}}=$ regression for the number of copies $(0,1,2)$ of $l$-th allele $(1=1,17)$ in the BoLA-DRB3 genotype; $\beta_{1} \mathrm{dd}_{\mathrm{ijkl}}=$ linear regression for days of lactation; $\beta_{2} \mathrm{dd}^{2}{ }_{\mathrm{ijkl}}=$ quadratic regression for days of lactation; $\beta_{3} \mathrm{wm}_{\mathrm{ijkl}}=$ linear regression for milk yield on the test day; and $\mathrm{e}_{\mathrm{ijkl}}=$ random error.

The statistical classification for lactation $\operatorname{lnSCC}$ fits contemporary group of herd-year-season of calving, lactation, regression on the number of copies of an allele, and linear and quadratic regression on days-in-milk.

\section{Results}

The average milk yield during the 305 days of lactation was $7702 \mathrm{~kg}$, fat and protein yield were $317 \mathrm{~kg}(4.23 \%)$ and $261 \mathrm{~kg}(3.35 \%)$, respectively (Table 1). The highest milk yield was recorded in lactation II $(8142 \mathrm{~kg})$ and the lowest in lactation IV+ $(6997 \mathrm{~kg})$. Accordingly, the highest yield of protein and fat was recorded in animals that were also in lactation II ( $274 \mathrm{~kg}$ of protein and $334 \mathrm{~kg}$ of fat) and the lowest in lactation IV+ $(240 \mathrm{~kg}$ of protein and $297 \mathrm{~kg}$ of fat). The average number of somatic cells in milk was $544,000 / \mathrm{mL}$. Such a value was observed in more than $25 \%$ of collected milk samples. Significant changes were observed in SCC during lactation (Figure 2). The highest SCC was recorded immediately after calving and the lowest values were observed before the dry-off (less than $50,000 / \mathrm{mL}$ ).

The highest polymorphism of BoLA-DRB3 gene was observed in herd 2, in which 68 alleles were identified, but this herd had the highest number of animals (440). The other two herds had a similar number of alleles, 48 in herd 3 and 49 in herd 1 . Of the 114 identified alleles, 17 occurred with a frequency higher than $2 \%$. Differences in the allele

Table 1 - Mean values of production and functional traits

\begin{tabular}{lcccc}
\hline \multirow{2}{*}{ Trait } & \multicolumn{4}{c}{ Lactation } \\
\cline { 2 - 5 } & I & II & III & IV \\
\cline { 2 - 5 } & \multicolumn{4}{c}{$\bar{X}$} \\
\hline Milk yield $(\mathrm{kg})$ & 7833 & 8142 & 7838 & 6997 \\
Fat yield $(\mathrm{kg})$ & 315 & 334 & 324 & 297 \\
Protein yield (kg) & 264 & 274 & 267 & 240 \\
Fat content (\%) & 4.14 & 4.21 & 4.24 & 4.36 \\
Protein content (\%) & 3.35 & 3.36 & 3.35 & 3.35 \\
Somatic cell count (thousands/mL) & 452 & 539 & 654 & 574 \\
Days of lactation (days) & 374 & 323 & 305 & 282 \\
\hline
\end{tabular}

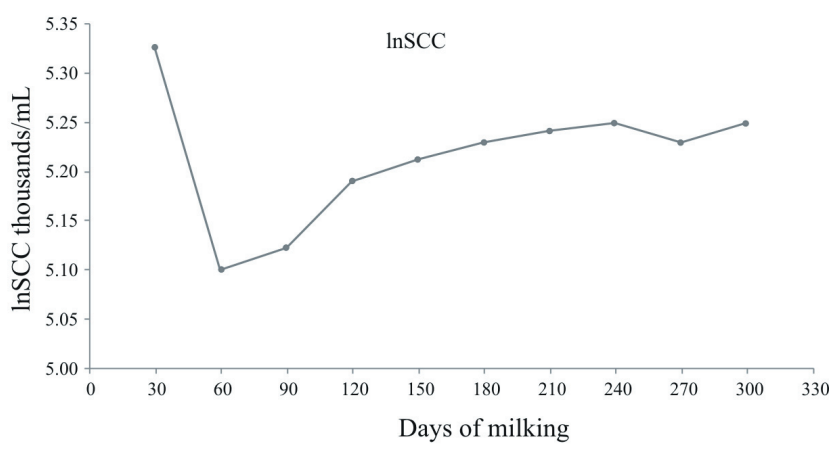

${ }^{1}$ Milking days were pooled in groups and an average $\operatorname{lnSCC}$ for each group is presented.

Figure 2 - Distribution of $\operatorname{lnSCC}$ in subsequent days of lactation ${ }^{1}$. 
frequencies between herds were found (Table 2). Alleles $* 8$ and $* 11$ were more numerous in the herd 3 . In our study, we found alleles of frequency exceeding $2 \%$, which presence have been previously reported in different populations of Holstein $(* 8, * 10, * 11, * 12, * 16, * 22, * 24, * 28, * 36, * 37)$, and also those which occurrence with frequency higher than $2 \%$ has not been yet confirmed in the literature (*jbd, *nbd, *gba, *neb, *jba, and *oeb). The frequency of the most numerous alleles (17) varied and ranged from $2.1 \%(* 12)$ to $19.8 \%(* 24)$. In herds 1 and 2, the BoLA$D R B 3$ gene was the most often represented by allele *24, with a frequency of $14.5 \%$ and $19.8 \%$, for herds 1 and 2 , respectively. In herd 3 , the most common alleles were $* 8$ and $* 11$, both appearing with a frequency of $12.8 \%$.

In herds 1 and 2, homozygotes that occurred most frequently were of the $B o L A-D R B 3 * 24 / 24$ genotype (Table 3). In both herds, the occurrence of this genotype was at similar level, 7.25 and $8.41 \%$ for herd 1 and 2,

Table 2 - Frequency ${ }^{1}$ of alleles of the $B o L A-D R B 3$ gene

\begin{tabular}{|c|c|c|c|}
\hline \multirow{2}{*}{$B o L A-D R B 3$} & \multicolumn{3}{|c|}{ Allele frequency (\%) } \\
\hline & Herd 1 & Herd 2 & Herd 3 \\
\hline$* 8$ & 11.4 & 11.9 & 12.8 \\
\hline$* 10$ & 2.6 & 2.3 & 3.1 \\
\hline$* 11$ & 3.1 & - & 12.8 \\
\hline$* 12$ & - & 2.1 & 8.7 \\
\hline$* 16$ & 6.7 & 4.1 & - \\
\hline$* 22$ & 11.9 & 9.2 & - \\
\hline$* 23$ & 8.5 & 3.9 & 4.7 \\
\hline$* 24$ & 14.5 & 19.8 & 7.5 \\
\hline$* 28$ & 2.8 & 6.2 & 9.5 \\
\hline *36 & 2.9 & - & - \\
\hline$* 37$ & - & - & 3.1 \\
\hline *jbd & 2.6 & 3.5 & - \\
\hline *nbd & 3.6 & 3.0 & - \\
\hline$*_{\mathrm{gba}}$ & 4.7 & 3.5 & 7.3 \\
\hline *neb & - & - & 2.5 \\
\hline$*$ jba & 2.3 & - & - \\
\hline *oeb & - & - & 3.4 \\
\hline$\sum 17$ alleles & 13 alleles & 11 alleles & 11 alleles \\
\hline
\end{tabular}

${ }^{1}$ Frequency equal to or greater than $2 \%$ in a particular herd. respectively, whereas in herd 3 , the $B o L A-D R B 3 * 11 / 11$ genotype was the most frequent $(7.43 \%)$.

Effects of substitution of 11 alleles of the BoLA-DRB3 gene on SCC were demonstrated in the study. The analysis of the relationship between the polymorphism of the locus and SCC was conducted in two schemes: estimating the effects for all lactations together or for each lactation separately. A significant relationship between the occurrence of the alleles of the BoLA-DRB3 gene and SCC was concluded. In case of estimating the effects for all lactations together, the effect of substitution was observed for 11 alleles (Table 4). The most favorable effects were observed for alleles $* 10$, $* 16$, $* 28$, and $*$ neb. Their presence in the genotype was associated with a significant decrease of SCC in milk. Milk of cows that carried alleles $* 12, * 22, * 23, * 24, *$ nbd, $*$ gba, and $*$ jba had elevated SCC. Values obtained in the analysis of each lactation separately confirmed those results. While comparing the lactation results estimated jointly or separately, contradictory results were observed in case of allele $* 22$. Its presence in the genotype was associated with a higher (for all lactations together and in lactation II) or lower (lactation IV+) SCC in milk. A similar situation was observed by comparing the effects estimated in each lactation, in which allele *oeb was associated with a higher $\operatorname{lnSCC}(0.26)$ in lactation I, but lower $(-0.32)$ in lactation $\mathrm{IV}+($ Table 5).

Analyzing the effects of particular lactations, it was also found that nine alleles showed positive relationship with SCC in lactation II. Only in case of allele *neb the effect of substitution contributed to reducing the SCC in milk. It was found that alleles $* 16, * 28$, and $*$ neb were closely related with decreased phenotypic value of SCC. The values obtained for these alleles were statistically significant when estimating for all lactations jointly and for each lactation separately. Estimating the effects also allowed to indicate the alleles that significantly contributed to the increased

Table 3 - Homozygotes of the BoLA-DRB3 gene by herd

\begin{tabular}{|c|c|c|c|c|c|c|c|c|}
\hline \multicolumn{3}{|c|}{ Herd 1} & \multicolumn{3}{|c|}{ Herd 2} & \multicolumn{3}{|c|}{ Herd 3} \\
\hline Allele & $\mathrm{N}$ & $\%$ & Allele & $\mathrm{N}$ & $\%$ & Allele & $\mathrm{N}$ & $\%$ \\
\hline$* 24 / * 24$ & 14 & 7.25 & $* 24 / * 24$ & 37 & 8.41 & $* 11 / * 11$ & 13 & 7.43 \\
\hline$* 22 / * 22$ & 9 & 4.66 & $* 08 / * 08$ & 11 & 2.50 & $* 08 / * 08$ & 9 & 5.14 \\
\hline$* 16 / * 16$ & 5 & 2.59 & $* 22 / * 22$ & 9 & 2.05 & $* 24 / * 24$ & 7 & 4.00 \\
\hline$* 08 / * 08$ & 4 & 2.07 & $* 03 / * 03$ & 4 & 0.91 & $* 28 / * 28$ & 6 & 3.43 \\
\hline$* 23 / * 23$ & 4 & 2.07 & $* 16 / * 16$ & 3 & 0.68 & $* 12 / * 12$ & 4 & 2.29 \\
\hline$* 10 / * 10$ & 1 & 0.52 & $* 11 / * 11$ & 2 & 0.45 & $* 03 / * 03$ & 1 & 0.57 \\
\hline$* 11 / * 11$ & 1 & 0.52 & $* 10 / * 10$ & 1 & 0.23 & $* 15 / * 15$ & 1 & 0.57 \\
\hline$* 28 / * 28$ & 1 & 0.52 & $* 23 / * 23$ & 1 & 0.23 & $* 23 / * 23$ & 1 & 0.57 \\
\hline$* 54 / * 54$ & 1 & 0.52 & $* 28 / * 28$ & 1 & 0.23 & $* 37 / * 37$ & 1 & 0.57 \\
\hline$* \mathrm{nbd} / *^{*} \mathrm{nbd}$ & 1 & 0.52 & & & & $*_{\text {naa } / * \text { naa }}$ & 1 & 0.57 \\
\hline$* \mathrm{gba} / *_{\mathrm{gba}}$ & 1 & 0.52 & & & & & & \\
\hline Total & 42 & 21.76 & & 69 & 15.69 & & 44 & 25.14 \\
\hline
\end{tabular}


SCC in milk. The effects of four alleles $(* 12, * 23, * 24$, and *ndb) proved to be statistically significant in the analysis of all lactations and their effects were repeated in at least two lactations in the analysis of each lactation separately. The most numerous relationships were found for allele *24, whose effects were statistically significant in lactations I to III in the analysis of all lactations.

Table 4 - Overall effect of substitution of an allele of the BoLA$D R B 3$ gene upon the natural logarithm of the lactation somatic cell count in milk

\begin{tabular}{|c|c|c|}
\hline \multirow{2}{*}{ BoLA-DRB3.2 } & \multicolumn{2}{|c|}{$\operatorname{lnSCC}$} \\
\hline & Effect & SE \\
\hline$* 8$ & 0.01 & 0.02 \\
\hline$* 10$ & $-0.17 \# \#$ & 0.03 \\
\hline$* 11$ & 0.05 & 0.03 \\
\hline$* 12$ & $0.08 \# \#$ & 0.03 \\
\hline$* 16$ & $-0.08 \# \#$ & 0.02 \\
\hline *22 & $0.06 \# \#$ & 0.02 \\
\hline$* 23$ & $0.06 \# \#$ & 0.02 \\
\hline$* 24$ & $0.06 \# \#$ & 0.01 \\
\hline$* 28$ & $-0.12 \# \#$ & 0.02 \\
\hline$* 36$ & 0.05 & 0.04 \\
\hline$* 37$ & 0.06 & 0.05 \\
\hline$*_{\mathrm{jbd}}$ & -0.01 & 0.04 \\
\hline$*_{n b d}$ & $0.12 \# \#$ & 0.04 \\
\hline *gba & $0.06 \#$ & 0.04 \\
\hline$*_{\text {neb }}$ & $-0.17 \# \#$ & 0.05 \\
\hline *jba & $0.17 \# \#$ & 0.04 \\
\hline *oeb & -0.04 & 0.06 \\
\hline
\end{tabular}

SE - standard error.

\# Significant at $\mathrm{P} \leq 0.05$.

\#\# Significant at $\mathrm{P} \leq 0.01$.

\section{Discussion}

Our results of the distribution of the most common alleles are consistent with data in the literature, as alleles $* 8, * 11$, and $* 24$ are reported as the most frequent in dairy herds (Dietz et al., 1997a; Sharif et al., 1998; Takeshima et al., 2003; Nassiry et al., 2008).

The main function of $B o L A-D R B 3$ gene is the expression of antigen-presenting proteins, and it has been associated with resistance and susceptibility to infectious diseases. For example, Starkenburg et al. (1997) observed a positive association of the $D R B 3 * 24$ allele with increased fat yield during first lactation in lines of Holstein cows selected for milk yield. The results of Pashmi et al. (2009) revealed significant positive relationships of alleles $* 22$ and $* 11$ with milk fat percent, as well as of alleles $* 24$ and *22 with protein percent.

Many authors emphasize the relationship between alleles of $B o L A-D R B 3$ gene and SCC as well as inflammatory conditions of the mammary gland (Kulberg et al., 2007; Rupp et al., 2007; Pashmi et al., 2009; Firouzamandi et al., 2010; Yoshida et al., 2011).

Kelm et al. (1997) found a link between an allele of $B O L A-D R B 3$ gene and a higher number of somatic cells and increased incidences of mastitis in animals with the $D R B 3 * 11$ and $D R B 3 * 16$ alleles. Significant associations between the polymorphism of BoLA-DRB3 gene and SCC were showen by Dietz et al. (1997a,b). According to these authors, the presence of allele *16 was associated with

Table 5 - Effect of substitution of BoLA-DRB3 gene alleles upon logarithm of the somatic cell count in milk across lactations

\begin{tabular}{|c|c|c|c|c|c|c|c|c|}
\hline \multirow{3}{*}{$B o L A-D R B 3$} & \multicolumn{8}{|c|}{$\operatorname{lnSCC}$} \\
\hline & \multicolumn{2}{|c|}{ Lactation I } & \multicolumn{2}{|c|}{ Lactation II } & \multicolumn{2}{|c|}{ Lactation III } & \multicolumn{2}{|c|}{ Lactation IV } \\
\hline & Effect & $\mathrm{SE}$ & Effect & $\mathrm{SE}$ & Effect & SE & Effect & $\mathrm{SE}$ \\
\hline$* 8$ & 0.03 & 0.03 & $0.15 \# \#$ & 0.03 & 0.05 & 0.04 & -0.06 & 0.03 \\
\hline$* 10$ & $-0.23 \# \#$ & 0.06 & -0.05 & 0.07 & -0.09 & 0.08 & -0.08 & 0.06 \\
\hline$* 11$ & $0.11 \#$ & 0.05 & 0.07 & 0.06 & 0.07 & 0.06 & 0.05 & 0.06 \\
\hline$* 12$ & 0.10 & 0.06 & $0.14 \#$ & 0.06 & $0.26 \# \#$ & 0.08 & 0.00 & 0.07 \\
\hline$* 16$ & 0.04 & 0.05 & -0.08 & 0.05 & $-0.18 \# \#$ & 0.06 & $-0.15 \# \#$ & 0.04 \\
\hline *22 & 0.05 & 0.03 & $0.07 \#$ & 0.04 & 0.06 & 0.04 & $-0.08 \#$ & 0.04 \\
\hline$* 23$ & $0.10 \#$ & 0.04 & $0.16 \# \#$ & 0.05 & -0.07 & 0.06 & -0.01 & 0.07 \\
\hline$* 24$ & $0.06 \#$ & 0.03 & $0.09 \# \#$ & 0.03 & $0.07 \#$ & 0.03 & -0.00 & 0.03 \\
\hline$* 28$ & -0.01 & 0.04 & -0.02 & 0.05 & $-0.22 \# \#$ & 0.06 & $-0.12 \#$ & 0.05 \\
\hline *36 & 0.06 & 0.08 & $0.18 \#$ & 0.09 & 0.12 & 0.10 & $0.30 \#$ & 0.11 \\
\hline *37 & $0.23 \#$ & 0.10 & $0.30 \# \#$ & 0.11 & -0.08 & 0.12 & -0.04 & 0.11 \\
\hline *jbd & 0.09 & 0.08 & -0.01 & 0.08 & -0.07 & 0.09 & 0.18 & 0.11 \\
\hline *nbd & 0.09 & 0.08 & $0.28 \# \#$ & 0.08 & $0.17 \#$ & 0.08 & -0.13 & 0.10 \\
\hline *gba & 0.11 & 0.06 & $0.15 \#$ & 0.07 & 0.05 & 0.09 & 0.12 & 0.09 \\
\hline *neb & -0.11 & 0.10 & $-0.25 \#$ & 0.11 & -0.10 & 0.12 & $-0.28 \#$ & 0.11 \\
\hline$* \mathrm{jba}$ & $0.25 \# \#$ & 0.08 & 0.15 & 0.09 & 0.13 & 0.09 & 0.15 & 0.10 \\
\hline *oeb & $0.26 \#$ & 0.12 & 0.02 & 0.13 & -0.25 & 0.14 & $-0.32 \#$ & 0.13 \\
\hline In total & \multicolumn{2}{|c|}{7844} & \multicolumn{2}{|c|}{6499} & \multicolumn{2}{|c|}{4889} & \multicolumn{2}{|c|}{5244} \\
\hline
\end{tabular}

SE - standard error.

\# Significant at $\mathrm{P} \leq 0.05$.

\#\# Significant at $\mathrm{P} \leq 0.01$ 
increased number of somatic cells, whereas allele $* 22$ was related to reduced SCC. In addition, the effects of alleles $* 11, * 12$, and $* 23$ were associated with a greater resistance to clinical mastitis.

Contradictory results were presented by Sharif et al. (1998) and Sender et al. (2008), who found that allele *16 was related with a lower SCC in milk and allele *23 with an increased SCC, thereby increasing the susceptibility to mastitis. Our research confirmed decreased value of $\operatorname{lnSCC}$ for allele *16 $(-0.08 ; \mathrm{P} \leq 0.01)$ and increased for allele *23 $(0.06 ; \mathrm{P} \leq 0.01)$ in the analysis of all lactations together. Significant influence $(\mathrm{P} \leq 0.01)$ of allele $* 24$ on phenotypic value of SCC in milk was also confirmed, which is consistent with previous studies of Kelm et al. (1997) and Starkenburg et al. (1997).

Rupp et al. (2007) showed that the presence of allele *3 in the genotype contributed to reducing the risk of inflammatory conditions of the mammary gland in cows, while the presence of allele $* 8$ in the genotype contributed to an increased risk of mastitis incidents. Pashmi et al. (2009) estimated the probability of the occurrence of subclinical udder inflammation, measured based on SCC, demonstrating positive effects of alleles $* 8, * 22$, and $* 51$. Kulberg et al. (2007) reported that alleles *22 and *26 could result in animal susceptibility to subclinical mastitis, whereas alleles $* 7, * 11, * 18$, and $* 24$ were associated with an increased resistance.

\section{Conclusions}

Since environmental effects can have a great impact on the somatic cell count of milk of older cows (cow age, medical history, etc.), it is suggested to consider only the effects of allele substitution for the first lactation. Further, since in estimating the relationship of allele substitution of the BoLA-DRB3 gene and somatic cell count, a high number of statistically significant effects was found, it can be concluded that the polymorphism in the studied locus may have a meaningful effect in creating resistance to mastitis.

\section{Acknowledgments}

The article was funded by the State Committee for Scientific Research in Poland, grant no. N31103731/0685.

\section{References}

Dietz, A. B.; Cohen, N. D.; Timms, L. and Kehrli Jr., M. E. 1997a. Bovine lymphocyte antigen class II alleles as risk factor for high somatic cell counts in milk of lactating dairy cows. Journal of Dairy Science 40:406-412.

Dietz, A. B.; Detilleux, J. C.; Freeman, A. E.; Kelley, D. H.; Stabel, J. R. and Kehrli Jr., M. E. 1997b. Genetic association of bovine lymphocyte antigen $D R B 3$ alleles with immunological traits in Holstein cattle. Journal of Dairy Science 80:400-405.

Duangjinda, M.; Buayai, D.; Pattarajinda, V.; Phasuk, Y.; Katawatin, S.; Vongpralub, T. and Chaiyotvittayaku, A. 2009. Detection of bovine leukocyte antigen DRB3 alleles as candidate markers for clinical mastitis resistance in Holstein x Zebu. Journal of Animal Science 87:469-476.

Fernández, I. G.; Ramírez, J. G. R.; Gayosso Vázquez, A.; Arvizu, R. U. and Morales, R. A. 2008. Polymorhism of locus DRB3.2 in populations of Creole cattle from Northen Mexico. Genetic and Molecular Biology 31:880-886.

Firouzamandi, M.; Shoja, J.; Barzegari, A. and Roshani, E. 2010. Study on the assiciation of BoLA-DRB3.2 alleles with clinical mastitis in Iranian Holstein and Sarabi (Iranian native) cattle. African Journal of Biotechnology 9:2224-2228.

Gillespie, B. E.; Jayarao, B. M.; Dowlen, H. H. and Oliver, S. P. 1999. Analysis and frequency of bovine lymphocyte antigen DRB3.2 Falleles in Jersey cows. Journal of Dairy Science 82:2049-2053.

Groenen, M. A. M.; van der Poel, J. J.; Dijkhof, R. J. M. and Giphart, M. J. 1990. The nucleotide-sequence of bovine MHC class-II $D Q B$ and $D R B$ genes. Immunogenetics 31:37-44.

Hameed, K. G. A.; Sender, G. and Korwin-Kossakowska, A. 2008. An association of BoLA alleles DRB3.2*16 and DRB3.2*23 with occurrence of mastitis caused by different bacterial species in two herds of dairy cattle. Animal Science Papers and Reports 26:37-48.

Juliarena, M. A.; Poli, M.; Ceriani, C.; Sala, L.; Rodriguez E.; Gutierrez, S.; Dolcini, G.; Odeon, A. and Esteban, E. N. 2009. Antibody response against tree widespread bovine viruses is not impaired in Holstein cattle carrying bovine leukocyte antigen DRB3.2 alleles associated with bovine leukemia virus resistance. Journal of Dairy Science 92:375-386.

Kanai, N.; Fujii, T.; Saito, K. and Tokoyama, T. 1994. Rapid and simple method for preparation of genomic DNA from easy obtainable collected blood. Journal of Clinical Pathology 47:1043-1044.

Kelm, S. C.; Detilleux, J. C.; Freeman, A. E.; Kehrli, M. E.; Dietz, A. B.; Fox, L. K.; Butler, J. E.; Kosckovics, I. and Helley, D. H. 1997. Genetic association between parameters of innate immunity and measures of mastitis in periparturient Holstein cattle. Journal of Dairy Science 80:1767-1775.

Kulberg, S.; Heringstad, B.; Guttersrud, O. A. and Olsaker, I. 2007. Study on the association of BoLA-DRB3.2 alleles with clinical mastitis in Norwegian Red cows. Journal of Animal Breeding and Genetics 124:201-207.

Nassiry, M. R.; Sadeghi, B.; Tohidi, R.; Afshari, J. T. and Khostavi, M. 2008. Comparison of bovine lymphocyte antigen DRB3.2 allele frequencies between two subpopulation of Iranian Holstein cattle. African Journal of Biotechnology 7:2671-2675.

Oprządek, J.; Urtnowski, P.; Sender, G.; Pawlik, A. and Łukaszewicz, M. 2012. Frequency of BoLA-DRB3 alleles in Polish HolsteinFriesian cattle. Animal Science Papers and Reports 30:91-101.

Pashmi, M.; Qanbari, S.; Ghorashi, S. A.; Sharif, A. R. and Simianer, H. 2009. Analysis of relationship between bovine lymphocyte antigen DRB3.2 alleles; somatic cell count and milk traits in Iranian Holstein population. Journal of Animal Breeding and Genetics 126:296-303.

Rupp, R.; Hernandez, A. and Mallard, B. A. 2007. Association of Bovine Leukocyte Antigen ( $B o L A) D R B 3.2$ with immune response; mastitis; and production and typed traits in Canadian Holstein. Journal of Dairy Science 90:1029-1038.

Russell, G. C.; Fraser, D. C.; Craigmile, S.; Oliver, R. A.; Dutia B. M. and Glass, E. J. 2000. Sequence and transfection of BoLA-DRB3 cDNA. Animal Genetics 31:219-222. 
Russell, G. C.; Smith, J. A. and Oliver, R. A. 2004. Structure of the BoLA-DRB3 gene and promoter. European Journal of Immunogenetics 31:145-151.

Sender, G.; Hameed, K. G. A.; Korwin-Kossakowska, A. and Sobczyńska, M. 2008. Association of the BoLA-DRB3 alleles with estimated breeding value for somatic cell count in Polish dairy cattle. Archiv für Tierzucht 51:111-119.

Sender, G.; Korwin-Kossakowska, A.; Hameed, G. A. K.; Oprządek, J. and Pawlik, A. 2013. Genetic basis of mastitis resistance in dairy cattle - a review. Annals of Animal Science 13:663-673.

Sharif, S.; Mallard, B. A.; Wilkie, B. N.; Sargeant, J. M.; Scott, H. M.; Dekkers, J. C. M. and Leslie, K. E. 1998. Association of the bovine major histocompatibility complex DRB3 (BoLA-DRB3) alleles with occurrence of disease and milk somatic cell score in Canadian dairy cattle. Animal Genetics 29:185-193.

Sharma, N.; Singh, N. K. and Bhadwal, M. S. 2011. Relationship of somatic cell count and mastitis: An overview. Asian-Australasian Journal of Animal Sciences 24:429-438.
Starkenburg, R. J.; Hansen, L. B.; Kehrli Jr., M. E. and Chester-Jones, H. 1997. Frequencies and effect of alternative DRB3 alleles of bovine lymphocyte antigen for Holsteins in milk selection and control lines. Journal of Dairy Science 80:3411-3419.

Takeshima, S-N.; Saitou, N.; Morita, M.; Inoko, H. and Aida, Y. 2003. The diversity of bovine MHC class II DRB3 genes in Japanese Black; Japanese Shorthorn; Jersey and Holstein cattle in Japan. Gene 316:111-118.

van den Elsen, P. J. 2011. Expression regulation of major histocompatibility complex class I and class II encoding genes. Frontiers in Immunology 2:48-49.

van Eijk, M. J. T.; Stewart-Haynes, J. A. and Lewin, H. A. 1992. Extensive polymorphism of the BoLA-DRB3 gene distinguished by PCR-RFLP. Animal Genetics 23:483-496.

Yoshida, T.; Furuta, H.; Kondo, Y. and Mukoyama, H. 2011. Association of BoLA-DRB3 alleles with mastitis resistance and susceptibility in Japanese Holstein cows. Animal Sciences Journal 83:359-366. 